Article

\title{
Antioxidant and Neuroprotective Potential of the Brown Seaweed Bifurcaria bifurcata in an in vitro Parkinson's Disease Model
}

\author{
Joana Silva ${ }^{1,2, *}$, Celso Alves ${ }^{1}$, Rafaela Freitas ${ }^{1}$, Alice Martins ${ }^{1}$, Susete Pinteus ${ }^{1}{ }^{1}$, \\ Joana Ribeiro ${ }^{1}$, Helena Gaspar 1,3 ${ }^{\mathbb{D}}$, Amparo Alfonso ${ }^{2}$ and Rui Pedrosa ${ }^{1, *}$ \\ 1 MARE-Marine and Environmental Sciences Centre, ESTM, Instituto Politécnico de Leiria, 2520-641 Peniche, \\ Portugal; celso.alves@ipleiria.pt (C.A.); rafaela.freitas@ipleiria.pt (R.F.); alice.martins@ipleiria.pt (A.M.); \\ susete.pinteus@ipleiria.pt (S.P.); joana.c.ribeiro@ipleiria.pt (J.R.); hmgaspar@fc.ul.pt (H.G.) \\ 2 Department of Pharmacology, Faculty of Veterinary, University of Santiago de Compostela, 27002 Lugo, \\ Spain; amparo.alfonso@usc.es \\ 3 BioISI-Biosystems \& Integrative Sciences Institute, Faculty of Sciences, University of Lisboa, Campo Grande, \\ C8, 1749-016 Lisboa, Portugal \\ * Correspondence: joana.m.silva@ipleiria.pt (J.S.); rui.pedrosa@ipleiria.pt (R.P.); \\ Tel.: +351-262-783-607 (J.S. \& R.P.); FAX: +351-262-783-088 (J.S. \& R.P.)
}

Received: 17 December 2018; Accepted: 23 January 2019; Published: 1 February 2019

check for updates

\begin{abstract}
Bifurcaria bifurcata is a marine brown seaweed mainly found on the Atlantic coast. Herein, we report the antioxidant and neuroprotective activities of seven fractions (F1-F7) obtained by normal phase chromatography from the B. bifurcata dichloromethane extract, as well as of its two major isolated diterpenes. Total phenolic content of fractions was determined by the Folin-Ciocalteu method, while antioxidant activity was evaluated by the DPPH, ORAC, and FRAP assays. Neuroprotective effects were evaluated in a neurotoxic model induced by 6-hydroxydopamine (6-OHDA) in a human neuroblastoma cell line (SH-SY5Y), while the mechanisms associated to neuroprotection were investigated by the determination of mitochondrial membrane potential, $\mathrm{H}_{2} \mathrm{O}_{2}$ production, Caspase-3 activity, and by observation of DNA fragmentation. Fractions F4 and F5 exhibited the best neuroprotective and antioxidant activities, respectively. F4 fraction prevented changes in mitochondrial potential, and induced a reduction of $\mathrm{H}_{2} \mathrm{O}_{2}$ levels production and an increase in cell viability, suggesting that it may contain multi-target compounds acting on different pathways. Hence, this fraction was subjected to purification steps, affording the known diterpenes eleganolone and eleganonal. Both compounds exhibited antioxidant potential, being interesting candidates for further neuroprotective studies.
\end{abstract}

Keywords: 6-hydroxydopamine; seaweeds; SH-SY5Y cells; neuroprotection; mitochondrial membrane potential; Caspase-3 activity; eleganolone; eleganonal; neurodegenerative diseases

\section{Introduction}

Parkinson's disease (PD) is a common neurodegenerative disease which affects the movement of aged population, and is characterized by the accumulation of Lewy bodies, loss of dopaminergic neurons in the substantia nigra of pars compacta (SNpc), and depletion of the neurotransmitter dopamine (DA) $[1,2]$. In recent years, many researchers have been focused on the prospection of new compounds from natural origin, since nature has proven to be a unique source of compounds with biomedical applications [3-5]. These metabolites may be intermediates or end-products of metabolism and are classified as primary metabolites which are essential for life, while the secondary ones participate in the natural defense of organisms [6]. The marine ecosystem can be regarded as an unlimited source 
of new secondary metabolites with unmatched chemical structures that can inspire the discovery of new drugs for the treatment of several pathologies, including PD [7,8]. Amongst the various marine organisms, seaweeds are a rich source of bioactive compounds that are not found in other organisms, exhibiting diverse biological activities, such as antioxidant, antitumor, antimicrobial, neuroprotector, antiviral, and anti-inflammatory, among others [9-11]. Seaweeds are one of the most accessible marine resources in the coastal zone, being classified in green, red, and brown algae [12]. Among the various species of macroalgae, only a limited number has been the subject of several studies because of their rich chemical composition and diversity of biological activity or health benefits, namely brown algae [13]. These algae have shown the ability to produce a wide variety of secondary metabolites with unique structures exhibiting various functionalities [14], particularly the algae Bifurcaria bifurcata. It can be found on the Atlantic coast (France, Spain, and Portugal) or on the west coast of Ireland [15], and has in their organic extracts several linear diterpenes rarely found in other brown species, [16]. Effectively, various in vitro biological effects of $B$. bifurcata extracts have been described, e.g., antioxidant, antimicrobial, and antitumor activities, which were attributed to the presence of these diterpenes [17-20]. Recently, a study reported by Alves et al. [19] demonstrated the bioactive potential of the methanolic and dichloromethane extracts of B. bifurcata regarding their antioxidant and antitumor properties, highlighting the importance of the isolation and identification of compounds that could be responsible for the bioactivities.

Pursuing our work on the study of the therapeutic potential of seaweeds collected in the Peniche coast, Portugal, we report now the antioxidant and neuroprotective activities of fractions obtained from $B$. bifurcata dichloromethane extract. In addition, the isolation and characterization of compounds isolated from the most bioactive fraction is presented, aiming to support and to rationalize the mechanisms of neuroprotection herein reported.

\section{Results and Discussion}

\subsection{Antioxidant Activity of B. bifurcata}

In the evaluation of the antioxidant activity of dichloromethane extract from B. bifurcata and derived fractions (F1-F7), different approaches have been outlined, namely, total phenolic content (TPC) determination by the Folin-Ciocalteu method, 2,2-diphenyl-1-picrylhydrazyl radical scavenging (DPPH) assay, oxygen radical absorbance capacity (ORAC) method, and ferric reducing antioxidant power (FRAP) assay. The results obtained are shown in Table 1.

Table 1. Antioxidant activity of dichloromethane extract and fractions from B. bifurcata collected in Peniche coast, Portugal.

\begin{tabular}{ccccc}
\hline Sample & TPC $^{\mathbf{a}}$ & DPPH $^{\mathbf{b}, *}$ & ORAC $^{\mathbf{c}}$ & FRAP $^{\mathbf{d}}$ \\
\hline Crude Extract & $10.63 \pm 1.40$ & $\begin{array}{c}43.34 \\
(36.90-50.81)\end{array}$ & $1886.55 \pm 60.57$ & $95.83 \pm 4.48$ \\
\hline F1 & $4.4 \pm 0.60$ & $\begin{array}{c}111.9 \\
(80.40-155.70)\end{array}$ & $353.23 \pm 9.89$ & $105.02 \pm 1.88$ \\
\hline F2 & $5.3 \pm 0.60$ & $>1000$ & $768.01 \pm 44.64$ & $221.37 \pm 11.77$ \\
\hline F3 & $3.08 \pm 0.30$ & $>1000$ & $412.55 \pm 14.44$ & $532.32 \pm 3.00$ \\
\hline F4 & $2.06 \pm 0.41$ & $>1000$ & $1407.01 \pm 44.56$ & $548.19 \pm 1.44$ \\
\hline F5 & $44.14 \pm 1.30$ & $\begin{array}{c}49.73 \\
(31.56-78.56)\end{array}$ & $4469.14 \pm 147.07$ & $1128.20 \pm 20.25$ \\
\hline F6 & $7.26 \pm 0.50$ & $\begin{array}{c}64.28 \\
(40.59-101.80)\end{array}$ & $334.15 \pm 49.65$ & $7.64 \pm 1.63$ \\
\hline F7 & $9.82 \pm 0.80$ & $\begin{array}{c}114.60 \\
(40.24-118.40)\end{array}$ & $2861.25 \pm 38.92$ & $573.44 \pm 33.79$ \\
\hline BHT & - & $\begin{array}{c}205.00 \\
(166.00-253.30)\end{array}$ & $143.70 \pm 23.36$ & $2821.50 \pm 63.03$ \\
\hline
\end{tabular}

${ }^{a}$ Gallic acid equivalents/extract $(\mathrm{mg} \mathrm{GAE} / \mathrm{g}){ }^{\mathrm{b}}{ }^{\mathrm{b}}$ radical scavenging activity $\left(\mathrm{IC}_{50} \mathrm{\mu g} / \mathrm{mL}\right) ;{ }^{\mathrm{c}}$ Trolox equivalents/extract $(\mu \mathrm{mol} \mathrm{TE} / \mathrm{g}) ;{ }^{\mathrm{d}} \mu \mathrm{M} \mathrm{FeSO}_{4} / \mathrm{g}$ extract. * $\mathrm{IC}_{50}$ values were determined for a $95 \%$ confidence interval. 
F5 fraction presented the highest phenolic content $(44.14 \pm 1.30 \mathrm{mg}$ gallic acid equivalents (GAE)/g extract), when compared to other fractions. Regarding the DPPH radical scavenging ability, F5 and F7 fractions presented the highest potential, being F5 the most potent one with an $\mathrm{IC}_{50}$ of $49.73 \mu \mathrm{g} / \mathrm{mL}$ (31.56-78.56) for a 95\% confidence interval. In the ORAC method, F5 and F7 fractions showed the highest antioxidant activity, $4469.14 \pm 147.07 \mu \mathrm{mol}$ of Trolox/g extract, and $2861.25 \pm$ $38.92 \mu \mathrm{mol}$ of Trolox/g extract, respectively. F5 fraction also revealed to be effective in reducing ferric ions (1128.20 $\pm 20.25 \mu \mathrm{M} \mathrm{FeSO}_{4} / \mathrm{g}$ extract) when compared with other fractions (Table 1).

The main components analysis (PCA) carried out in this study allowed us to relate all the methods used to evaluate the antioxidant capacity (DPPH, ORAC, and FRAP) and total phenolic content (TPC). It is possible to observe the clear arrangement of three groups that differ according to their antioxidant activity (Figure 1).

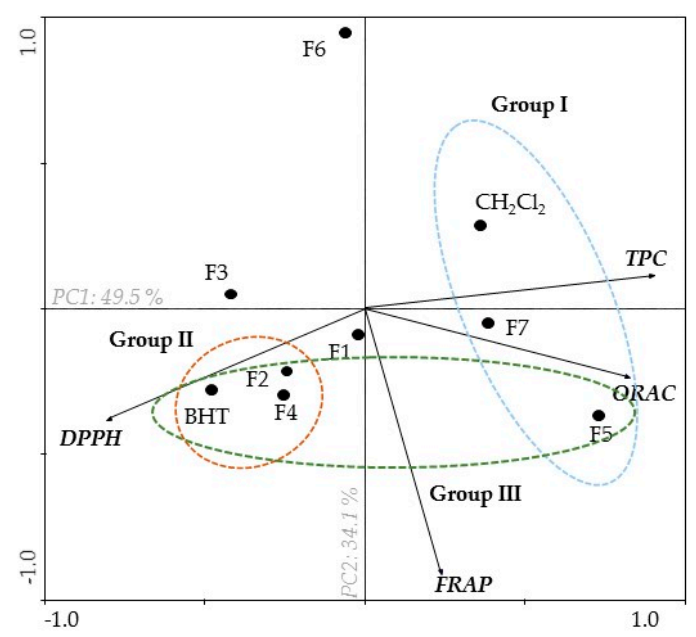

Figure 1. Principal component analysis (PCA) of total phenolic content (TPC) and antioxidant activities (DPPH, ORAC, FRAP) of B. bifurcata dichloromethane extract $\left(\mathrm{CH}_{2} \mathrm{Cl}_{2}\right)$, fractions (F1-F7), and standard (BHT).

As referred to above, this PCA was carried out to obtain an overview of the similarities and differences among the seven fractions from B. bifurcata dichloromethane extract, and to investigate the relationships between TPC and the different antioxidant activity assays. The first two main components explained $49.5 \%$ and $34.1 \%$ of the total variance in the dataset, respectively (Figure 1 ). The horizontal axis expresses an opposition between DPPH (left) and TPC (right), verified in the first principal component (PC1) analysis. Moreover, TPC presented a negative correlation with DPPH, but showed a positive correlation with FRAP and ORAC (Figure 1). DPPH radical scavenging activity is expressed by $\mathrm{IC}_{50}$, and it is possible to verify that fractions presenting high phenolic content also exhibit high DPPH radical scavenging activity (Group I). On the other hand, F2 and F4 fractions showed low levels of TPC, and exhibited low DPPH radical scavenging activity (Group II) (Figure 1). However, F5 and F7 fractions showed high FRAP and ORAC values when compared with F3 and F6 fractions (the second principal component (PC2) explained the variation between samples with regard to peroxyl radical scavenging activity (ORAC) and ferric reducing power (FRAP).

In fact, the existence of a correlation between total phenolic content and antioxidant capacity has been reported by several authors [21-23]. According to the results obtained, it is possible to verify this relation in the PCA, in which the fractions that presented high total content of polyphenols also presented a high capacity of radical DPPH reduction. These data suggest that the observed relationship can be mediated by molecules such as polyphenols, which are good antioxidants because of their redox properties, which allow them to act as reducing agents [22,24], and hydrogen $\left(\mathrm{H}^{+}\right)$donors, contributing to the production of less reactive radicals, and for the removal of metal ions [25-27]. This mechanism plays an important role in preventing oxidation processes associated with the development of different 
pathologies such as neurodegenerative diseases [19]. In addition, previous studies have already demonstrated that B. bifurcata had interesting antioxidant activities, corroborating the results obtained in this study $[10,19,27,28]$. Among the compounds present in brown seaweeds, the phlorotannins are strong candidates to mediate those activities, since they are included in the major group of phenolic compounds, are abundant in brown algae, and are also reported for their enormous antioxidant potential. Li et al. [29] fractionated the brown algae Sargassum fusiforme with ethanol, ethyl acetate, and butanol for the extraction of phlorotannins, and found that the ethyl acetate fraction showed the highest phlorotannin content expressed in phloroglucinol equivalents (PGE) (884.8 mg PGE/g extract). From the ethyl acetate fraction, these authors isolated four phlorotannins, belonging to the classes of fuhalols, fucophlorethols, phlorethols, and eckols. Leyton et al. [28] studied the phlorotannin content of the brown alga Macrocystis pyrifera. They used different solvents, e.g., water, methanol, ethyl acetate, chloroform, and ethanol/water (70:30), the latter showing the highest total phlorotannin content (140 mg PGE/g extract). These studies are in agreement with the results obtained in our work, suggesting that the presence of phenolics, like polyphenols and phlorotannins, in B. bifurcata extracts and fractions, are responsible for their antioxidant properties. In recent years, antioxidant compounds, e.g., phenolics and other groups of compounds (diterpenes, polysaccharides, alkaloids) have shown promising therapeutic potential as agents that may delay the process associated with neuronal cell loss in neurodegenerative diseases such as PD [30-33].

\subsection{Neuroprotective Effect of B. bifurcata on SH-SY5Y Cells Exposed to 6-OHDA}

The cytotoxic effects of B. bifurcata fractions on SH-SY5Y cells were evaluated. Fractions with no cytotoxicity were further tested for their neuroprotective potential on SH-SY5Y cells after exposure to the neurotoxin 6-OHDA. Cells were treated with B. bifurcata fractions $(1 \mu \mathrm{g} / \mathrm{mL})$ for $24 \mathrm{~h}$, and cell viability was evaluated by the MTT method. The results are presented in Figure 2.

A

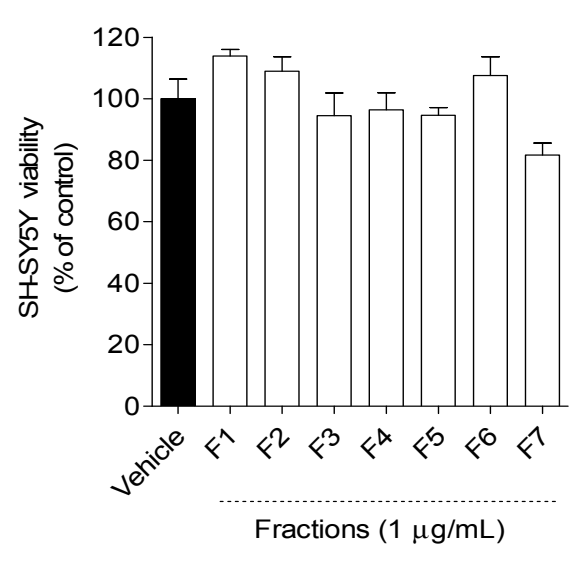

B

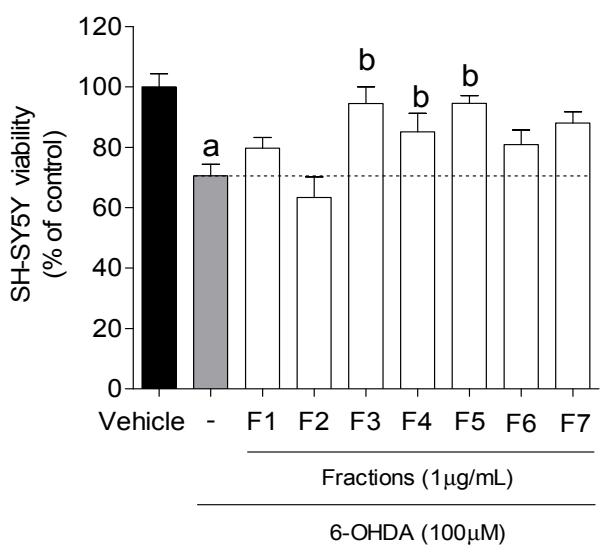

Figure 2. (A) Cytotoxicity of B. bifurcata fractions ( $1 \mu \mathrm{g} / \mathrm{mL}, 24 \mathrm{~h})$ on SH-SY5Y cells; (B) Neuroprotective effects of B. bifurcata fractions $(1 \mu \mathrm{g} / \mathrm{mL})$ on SH-SY5Y cells during $24 \mathrm{~h}$ of incubation with 6-OHDA. The values in each column represent the mean \pm standard error of the mean (SEM) of 3 or 4 independent experiments. Evaluation of statistical significance was performed using one-way ANOVA with Dunnett's multiple comparison test $(p$ value $<0.05)$. Symbols represent statistically significant differences when compared to: ${ }^{a}$ vehicle. ${ }^{b}$ to 6-OHDA.

The exposition of SH-SY5Y cells to 6-OHDA $(100 \mu \mathrm{M})$ led to a reduction of about $30 \%(70.61 \%$ $\pm 3.73 \%$ of viable cells) of cell viability after $24 \mathrm{~h}$ incubation when compared to vehicle $(100 \pm 4.43$ of viable cells). However, when 6-OHDA was incubated with fractions $(1 \mu \mathrm{g} / \mathrm{mL})$, the F3, F4 and F5 fractions exhibited the ability to revert its neurotoxic effect on cell viability to about 20-25\% (Figure 2).

The decrease of neurotoxicity associated with 6-OHDA mediated by extracts and compounds has been reported by several scientific studies $[2,9,34]$. For instance, a previous study carried out 
by our group demonstrated the neuroprotective effect of several extracts of macroalgae in SH-SY5Y cells when exposed to 6-OHDA, inducing an increase of $15-35 \%$ of cell viability at a concentration of $1 \mathrm{mg} / \mathrm{mL}$ [9]. On the other hand, Ba et al. [35] found that co-treatment with schisandrin B, isolated from a plant, increased cell viability in 35\% $(40.05 \mu \mathrm{g} / \mathrm{mL})$ in SH-SY5Y cells in the presence of 6-OHDA. Lou et al. [36] isolated naringenin from a fruit and found that co-treatment with this compound resulted in an increase in cell viability of $30 \%(21.78 \mu \mathrm{g} / \mathrm{mL})$ in SH-SY5Y cells also treated with 6-OHDA. The neuroprotective effect demonstrated by these compounds was somewhat similar to that obtained with B. bifurcata fractions. However, the concentrations tested by the authors were higher $(>1 \mu \mathrm{g} / \mathrm{mL}$ ) when compared to the concentration used in this study. Therefore, the results obtained are quite promising, since these samples are crude fractions, which are still composed of a variety of molecules that, once isolated and purified, can have their in vitro neuroprotective effects potentiated.

\subsection{Cellular Mechanisms Associated with the Neuroprotective Effect of B. bifurcata}

To investigate if the neuroprotective effect demonstrated by B. bifurcata on the viability of SH-SY5Y cells was associated with PD hallmarks, different in vitro assays were performed (mitochondrial membrane potential, production of $\mathrm{H}_{2} \mathrm{O}_{2}$, Caspase-3 activity, and DNA fragmentation) on cells treated with the neurotoxin 6-OHDA in the absence or presence of fractions from B. bifurcata. The incubation times were defined according to the highest effects promoted by 6-OHDA for each mechanism, verified in preliminary studies. The treatment with the F1-F7 fractions did not change the results of the mitochondrial potential, $\mathrm{H}_{2} \mathrm{O}_{2}$ production, and Caspase- 3 activity when compared with the vehicle (cells without treatment), per se. However, for a clear understanding of the results, all the data were presented as percentage of control. The results are presented in Figures 3-7.

The membrane mitochondrial potential (MMP) determination allowed us to measure the mitochondrial dysfunction and to understand if the neuro protective effect of B. bifurcata was mediated by biological events on mitochondria. The exposition of SH-SY5Y cells to 6-OHDA (100 $\mu \mathrm{M}, 6 \mathrm{~h})$ induced a strong depolarization of the MMP when compared with the vehicle $(p<0.05)$ (Figure 3$)$. During the treatment with seaweed fractions, it was possible to observe a noticeable preventive effect of F4 (218.10\% $\pm 14.87 \%$ of vehicle) and F5 fractions (150.51\% $\pm 16.98 \%$ of vehicle) in the depolarization induced by $6-\mathrm{OHDA}(421.48 \% \pm 57.05 \%$ of vehicle) exposition. On the contrary, F3 enhanced the mitochondrial dysfunction.

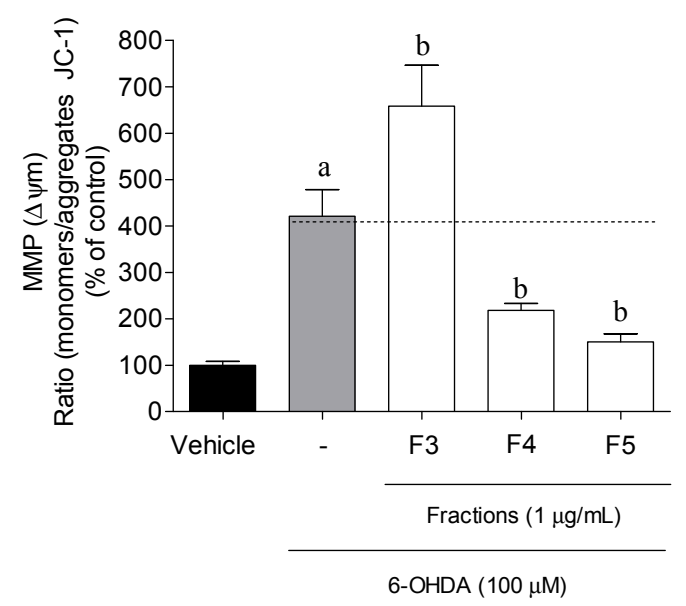

Figure 3. Mitochondrial membrane potential of SH-SY5Y cells after $6 \mathrm{~h}$ of incubation with 6-OHDA $(100 \mu \mathrm{M})$ in the absence or presence of B. bifurcata fractions $(1 \mu \mathrm{g} / \mathrm{mL})$. Results were obtained by the ratio between the monomers/aggregates of JC- 1 . The values in each column represent the mean \pm standard error of the mean (SEM) of 3 or 4 independent experiments. One-way ANOVA with Dunnett's multiple comparison test was conducted to evaluate statistical significance ( $p$ value $<0.05)$. Symbols represent statistically significant differences when compared to ${ }^{\mathrm{a}}$ vehicle and ${ }^{\mathrm{b}}$ 6-OHDA. 
The levels of $\mathrm{H}_{2} \mathrm{O}_{2}$ production were measured to evaluate the ability of $B$. bifurcata fractions to prevent the condition of oxidative stress induced by the neurotoxin (Figure 4). SH-SY5Y cells, when exposed to 6-OHDA (100 $\mu \mathrm{M}, 12 \mathrm{~h})$, experienced an increase of more than twice the $\mathrm{H}_{2} \mathrm{O}_{2}$ levels when compared with vehicle $(p<0.05)$. Moreover, when B. bifurcata fractions were administered at $1 \mu \mathrm{g} / \mathrm{mL}$, only F4 showed a significant effect in the decrease of the levels of $\mathrm{H}_{2} \mathrm{O}_{2}(204.50 \% \pm 15.12 \%$ of vehicle) as compared to 6 -OHDA $(268.73 \% \pm 20.03 \%$ of the vehicle) treatment.

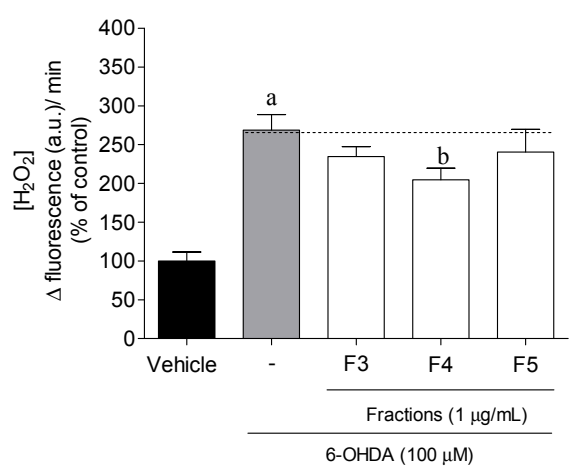

Figure 4. Levels of hydrogen peroxide $\left(\mathrm{H}_{2} \mathrm{O}_{2}\right)$ produced by SH-SY5Y cells after $12 \mathrm{~h}$ of incubation with 6-OHDA $(100 \mu \mathrm{M})$ in the presence or absence Bifurcaria bifurcata fractions $(1 \mu \mathrm{g} / \mathrm{mL}) \cdot \mathrm{H}_{2} \mathrm{O}_{2}$ was quantified fluorometrically using the Amplex Red Hydrogen Peroxide/Peroxidase Assay kit. The values in each column represent the mean \pm standard error of the mean (SEM) of 3 or 4 independent experiments. One-way ANOVA with Dunnett's multiple comparison test was conducted to evaluate statistical significance $(p$ value $<0.05)$. Symbols represent statistically significant differences when compared to ${ }^{a}$ vehicle and ${ }^{b} 6-O H D A$.

Caspase-3 activity was measured to understand if the B. bifurcata fractions had capability to prevent the cell death mediated by apoptosis when exposed to the neurotoxin (Figure 5). The treatment of SH-SY5Y cells with 6-OHDA ( $100 \mu \mathrm{M}, 6 \mathrm{~h})(233.58 \% \pm 13.78 \%$ of vehicle) has shown an increase of Caspase-3 activity compared with vehicle. Fraction F5 had an effect on this enzyme that was similar to $6-\mathrm{OHDA}$, while F3 $(120.11 \% \pm 11.00 \%$ of vehicle) and F4 $(164.24 \% \pm 8.31 \%$ of vehicle) fractions showed a decreased Caspase-3 activity when compared with 6-OHDA.

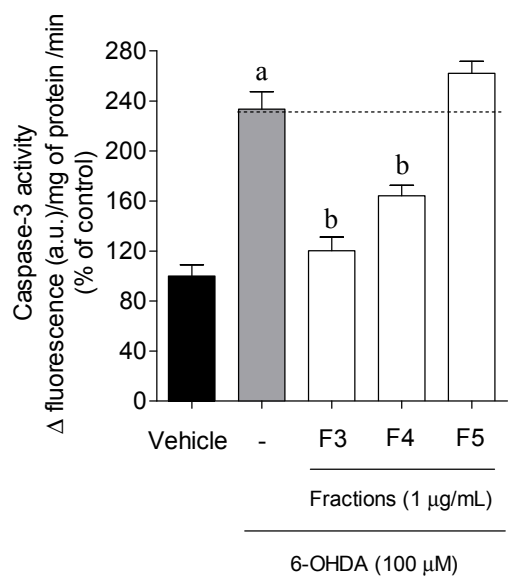

Figure 5. Effects of 6-OHDA $(100 \mu \mathrm{M})$ in the absence or presence of B. bifurcata fractions $(1 \mu \mathrm{g} / \mathrm{mL})$ on Caspase-3 activity of SH-SY5Y cells after $6 \mathrm{~h}$ of treatment. The activity was quantified by the slope of the linear phase accumulation of rhodamine 110 (between 20 and $40 \mathrm{~min}$ ). The results are presented in arbitrary units of fluorescence per $\mathrm{mg}$ protein per min. The values in each column represent the mean \pm standard error of the mean (SEM) from 3 to 4 experiments. One-way ANOVA with Dunnett's multiple comparison test was conducted to evaluate statistical significance ( $p$ value $<0.05$ ). Symbols represent statistically significant differences when compared to ${ }^{a}$ vehicle and ${ }^{b} 6$-OHDA. 
To understand if B. bifurcata fractions had the ability to prevent the DNA fragmentation induced by 6-OHDA treatment, the integrity of SH-SY5Y DNA was evaluated through staining with DAPI probe. Cell death by apoptosis was also investigated through fluorescence microscopy after DAPI staining. Nuclear condensation and fragmentation, which are characteristic features of apoptosis, were found for neuroblastoma cells treated with 6-OHDA $(100 \mu \mathrm{M}, 24 \mathrm{~h})$ (Figure 6). The obtained images are representative of one experiment. However, it was possible to verify that treatment with fractions of $B$. bifurcata can inhibit nuclear condensation and fragmentation, and the protective effect of F4 fraction against 6-OHDA-induced apoptosis was verified.

Overall, the data concerning the cellular mechanisms behind the neuroprotective activity of $B$. bifurcata suggest that the effect demonstrated by F4 fraction is mediated by a reduction of oxidative stress condition via $\mathrm{H}_{2} \mathrm{O}_{2}$ production pathway and an anti-apoptotic effect (mitochondrial protection, decrease of Ccaspase-3 activity, and decrease of DNA condensation) which has not been verified for F3 and F5 fractions.
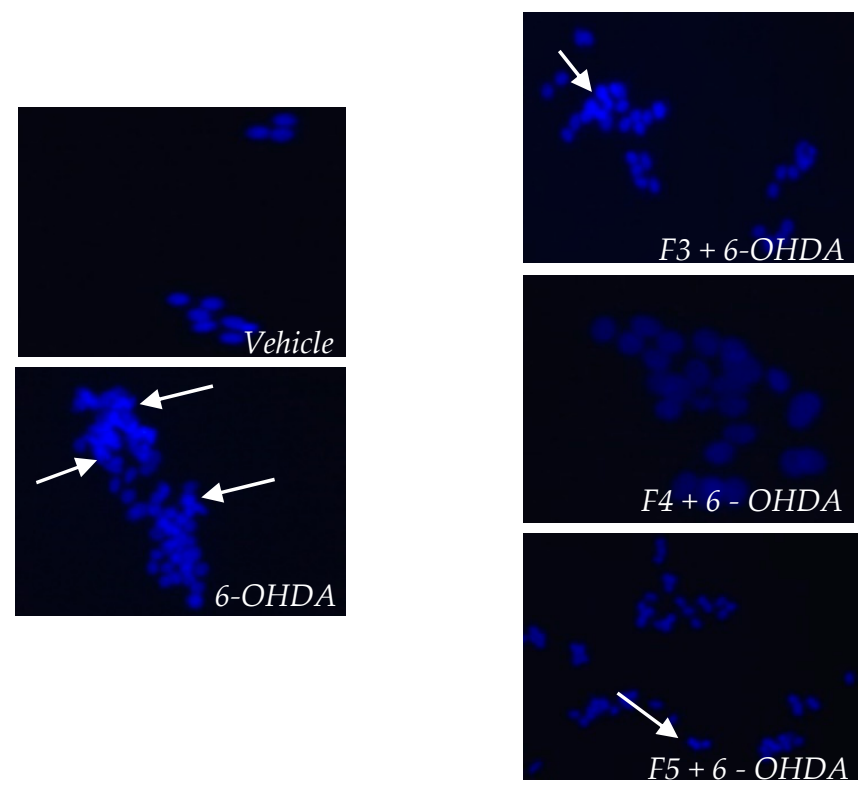

Figure 6. Nuclear morphology of SH-SY5Y cells stained with DAPI probe. SH-SY5Y cells stained with DAPI showing the anti-apoptotic effect of the fractions F3, F4 and F5 of Bifurcaria bifurcata $(1 \mu \mathrm{g} / \mathrm{mL})$ against neurotoxicity mediated by $6-\mathrm{OHDA}(100 \mu \mathrm{M} ; 24 \mathrm{~h})$. The fragmentation pattern is an indicator of apoptosis. * The images are representative of one experiment.

Mitochondria produce more than $90 \%$ of cellular energy through oxidative phosphorylation, which involves the Krebs cycle and the electron carrier chain. However, about $1 \%$ to $2 \%$ of the electrons are released through the complexes I and III of the electron transport chain, reacting with molecular oxygen and forming ROS sequentially as $\mathrm{O}_{2}{ }^{-\bullet}$ and $\mathrm{H}_{2} \mathrm{O}_{2}$, which can be converted to water through the peroxisome. An increase of ROS levels in mitochondria may activate apoptotic pathways, leading to cell death. Thus, a blockade of the complex I can result in mitochondrial dysfunction culminating in several consequences, namely, the increase of $\operatorname{ROS}\left(\mathrm{H}_{2} \mathrm{O}_{2}\right)$ and a decrease of ATP production and cell damage $[37,38]$. Based on these facts, the decrease in the neurotoxic effect of 6-OHDA, evidenced by the F4 fraction, clearly appears to be associated with different mechanisms that are intercorrelated, in this case, to a decrease in $\mathrm{H}_{2} \mathrm{O}_{2}$ production and mitochondrial depolarization. These results are in agreement with those obtained by Cui et al. [39], which demonstrated that SH-SY5Y cells submitted to neurotoxic effects induced by 6-OHDA, and that treatment with a sulfated polysaccharide isolated from the sea cucumber Stichopus japonicus prevented changes in mitochondrial membrane potential, induced a reduction of ROS level, and increased cell viability. Kich et al. [40] also demonstrated that in SH-SY5Y cells treated with 6-OHDA, the presence of Calyptranthes grandifolia extracts prevented 
alterations in mitochondrial potential and reduced the levels of $\mathrm{H}_{2} \mathrm{O}_{2}$ production. Several studies have shown that neuronal death in PD is associated with the release of cytochrome $\mathrm{C}$ and, consequently, activation of the caspase cascade, namely caspase-3, which plays an important role in the process of cell death by apoptosis characterized by cellular shrinkage and nuclear condensation [41,42]. According to our results, it was possible to verify that the F4 fraction caused an inhibition of Caspase- 3 and reversed the morphological damage induced by 6-OHDA. These results suggest that the increasing of cell viability may be mediated by an effect on the apoptosis process, which is in accordance with several studies in which the use of different molecules exhibited anti-apoptotic effects, namely by decreasing caspase and reversing the morphological damage caused by $6-\mathrm{OHDA}[39,43,44]$. In this study, the F4 fraction demonstrated the highest neuroprotective activity, which seems to be related with a decrease of oxidative stress condition via $\mathrm{H}_{2} \mathrm{O}_{2}$ production, and an anti-apoptotic effect as described before. These results led us to hypothesize the mechanism of action represented in Figure 7.

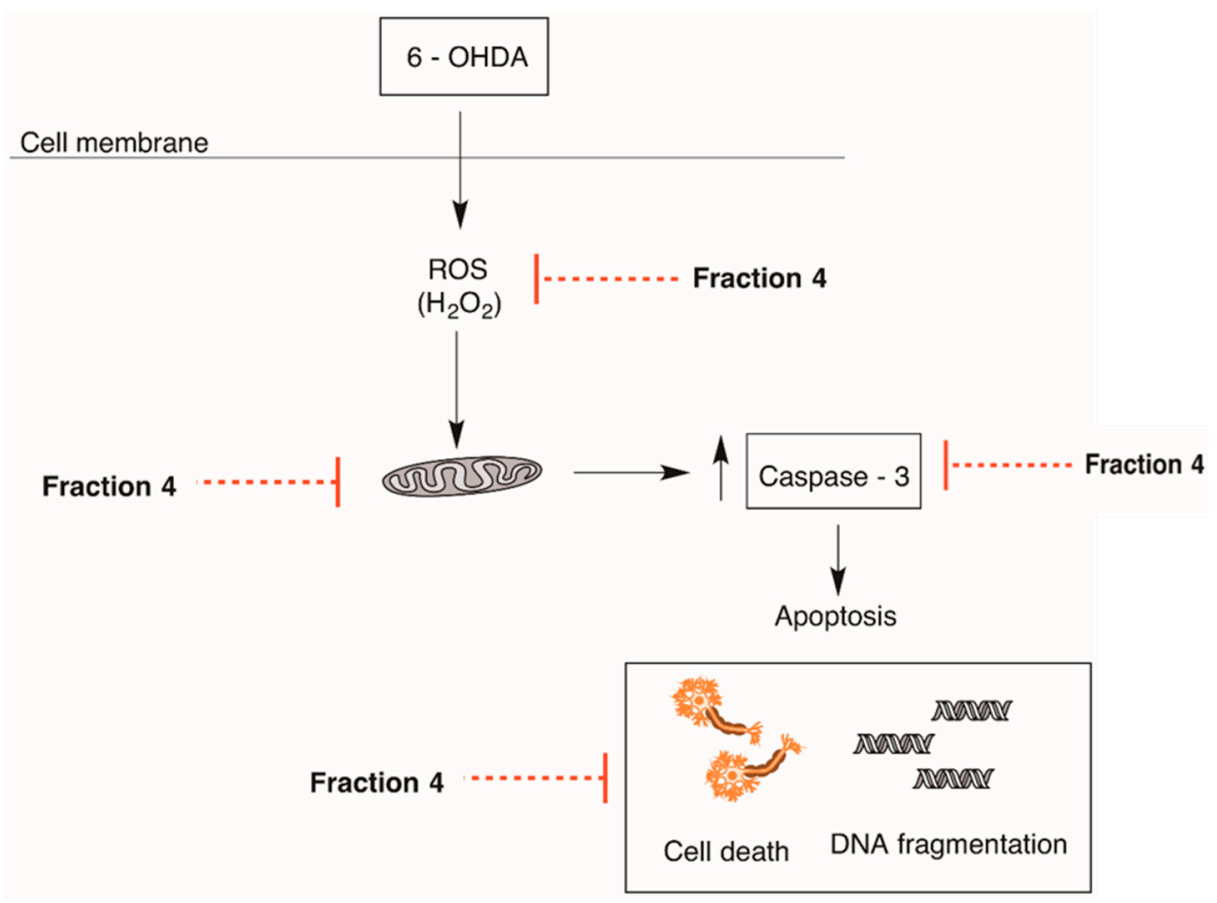

Figure 7. Schematic hypothesis of neuroprotective mechanism mediated by F4 fraction derived from Bifurcaria bifurcata on 6-OHDA-injured SH-SY5Y cells.

\subsection{Isolation and Antioxidant Activity of B. bifurcata Compounds}

Since the F4 fraction from B. bifurcata revealed the best neuroprotective activity, it was subjected to more refined fractionation by semi-preparative HPLC, aiming to isolate the potential bioactive molecules. Two major compounds, eleganolone (1) and eleganonal (2), were obtained (Figure 8), whereby the latter was obtained after further purification by preparative TLC.

The structures of both metabolites were established by nuclear magnetic resonance (NMR), and by comparison of their spectral data with those described in the literature $[18,45]$.

Eleganolone was described by Ghothel et al. [18] and eleganonal was reported for the first time by Culioli et al. [46]. These two compounds belong to the family of diterpenes and are usually found in this species $[17,18,45-48]$.

Although both compounds have already been described a few years ago, much remains to be explored regarding their biological potential. Only Gallé et al. [17] evaluated the anti-protozoal activity of eleganolone (1) against Plasmodium falciparum and Leishmania donovani, as well as its cytotoxic activity on mammalian L6 cell line, concluding that eleganolone could be the active compound against P. falciparum. 
<smiles>CC(C)=CC(=O)CC(C)=CCCC(C)=CCCC(C)=CCO</smiles>

(1) Eleganolone<smiles>CC(C)=CC(=O)C/C(C)=C/CC/C(C)=C/CC/C(C)=C/C=O</smiles>

(2) Eleganonal

Figure 8. Structures of the compounds $\mathbf{1}$ and $\mathbf{2}$.

The antioxidant activity of eleganolone (1) and eleganonal (2) isolated from B. bifurcata was evaluated by the DPPH, ORAC, and FRAP methods to verify if both compounds contributed, or not, to the antioxidant activity presented by F4 fraction. The results are presented in Table 2.

Table 2. Antioxidant activity of compounds eleganolone (1) and eleganonal (2) isolated from B. bifurcata F4 fraction.

\begin{tabular}{cccc}
\hline Compounds & DPPH $^{\text {a }}$ & ORAC $^{\mathbf{b}}$ & FRAP $^{\mathbf{c}}$ \\
\hline Eleganolone (1) & $>100$ & $1663.83 \pm 25.35$ & $8341.18 \pm 177.72$ \\
Eleganonal (2) & $>100$ & $667.48 \pm 10.96$ & $8635.37 \pm 389.54$ \\
BHT & $>100$ & $143.70 \pm 23.36$ & $2821.50 \pm 63.03$ \\
\hline a Radical scavenging activity $\left(\mathrm{IC}_{50} \mu \mathrm{M}\right) ;^{\mathrm{b}} \mu \mathrm{mol} \mathrm{TE} / \mathrm{g}$ of compound; ${ }^{\mathrm{c}} \mu \mathrm{M} \mathrm{FeSO}_{4} /$ g compound. $^{2}$
\end{tabular}

As can be seen in Table 2, both compounds did not demonstrate a significant ability to reduce the DPPH radical, when compared to the fraction from which they were isolated. However, the compounds showed a high potential in reducing peroxyl radicals and have a strong iron reduction capacity, when compared to the synthetic antioxidant BHT.

An increase in iron and other metal ions may be associated with neurodegenerative diseases, namely PD, in the substantia nigra (SNpar) region. During aging, the concentration of iron can change in the brain, leading to a metabolic stress condition $[49,50]$. Since SNpar has a high metabolic rate of dopamine, neuromelanin, iron, and low antioxidant content, such as reduced glutathione, lead to an increase of oxidative stress. The production of ROS thus results in mitochondrial alterations that will contribute to the disappearance of dopaminergic neurons [51]. In this way, the potential of both compounds, in particular eleganolone (1), in reducing iron may be interesting for future exploitation aiming at the prevention and/or treatment of PD. Currently, in vitro studies regarding the evaluation of the neuroprotective effects of both compounds are under development.

In conclusion, fraction F5 presented the best antioxidant potential in all the assays here described. However, fraction $\mathrm{F} 4$ revealed to have the highest neuroprotective effects which could be associated with the reduction of $\mathrm{H}_{2} \mathrm{O}_{2}$ production, protection of mitochondrial membrane potential, and inhibition of Caspase-3 activity. The compounds eleganolone (1) and eleganonal (2), obtained from this fraction, demonstrated antioxidant potential by FRAP and ORAC assays, revealing themselves to be excellent candidates for further neuroprotection assays aiming the prevention and/or treatment of PD. Currently, more studies on both compounds are being developed.

\section{Materials and Methods}

\subsection{Chemicals and Reagents}

Solvents for chromatographic techniques were HPLC quality grade (VWR, Fontenay-sous-Bois, France). VLC was performed on Kieselgel 60-200 $\mu \mathrm{m}$ (VWR, Ref. 84893.290, Leuven, Belgium), TLC on Kieselgel $60 \mathrm{~F}_{254}$ aluminium sheets (Merck, Ref. 5554, Darmstadt, Germany), were used for TLC while PTLC was performed on Kieselgel $60 \mathrm{~F}_{254}$ glass plates (Merck, Ref. 5744, Darmstadt, Germany). 
For TPC determination, Folin reagent (Scharlau, Barcelona, Spain) and sodium carbonate (Panreac, Barcelona, Spain) were used. Antioxidant activity determination was accomplished by using the following reagents: TPTZ, $\mathrm{FeCl}_{3}$, and DPPH (Sigma, Steinheim, Germany), $\mathrm{FeSO}_{4}$ (Sigma, Karnataka, India), fluorescein, APPH, and Trolox (Sigma, St. Louis, MO, USA).

Concerning the determination of neuroprotective activities, the following reagents were used: DMEM/F12, trypsin 1×, and FBS (Biowest, Riverside, MO, USA), antimicotic (Sigma, Rehovot, Israel), and MTT (VWR, Fontenay-sous-Bois, France). The hallmarks associated with oxidative stress and apoptosis were evaluated by using JC-1, Amplex Red Hydrogen Peroxide/Peroxidase Assay kit and DAPI (Molecular probes, Loughborough, UK), and Caspase-3 Activity Fluorimetric kit (Sigma, Rehovot, Israel).

\subsection{Seaweed Collection}

Freshly samples of B. bifurcata were collected between May and June 2015, at Baleal Beach $\left(39^{\circ} 37^{\prime} 68.32^{\prime \prime} \mathrm{N} 9^{\circ} 34^{\prime} 01.12^{\prime \prime} \mathrm{W}\right)$, Peniche (Portugal), and immediately transported to MARE-IPLeiria facilities. The samples were cleaned and washed with seawater to remove epiphytes, detritus, and encrusting material. After that, the clean material was freeze-dried (Scanvac Cool Safe, LaboGene, Lynge, Denmark), ground, and stored at $-80^{\circ} \mathrm{C}$ until further use.

\subsection{Extraction and Fractionation of B. bifurcata}

Freeze-dried samples of B. bifurcata ( $2.2 \mathrm{~kg}, 15 \%$ of wet seaweed), were sequentially extracted with $\mathrm{MeOH}$ and $\mathrm{CH}_{2} \mathrm{Cl}_{2}$ (in a biomass/solvent ratio of 1:40) at constant stirring for $12 \mathrm{~h}$. Each resulting solution was filtrated, and the corresponding organic phase was evaporated under reduced pressure on a rotary evaporator (IKA HB10), at $40{ }^{\circ} \mathrm{C}$. The $\mathrm{CH}_{2} \mathrm{Cl}_{2}$ extract $(22 \mathrm{~g}, 0.95 \%$ of freeze-dried seaweed) was further concentrated and subjected to normal phase VLC on silica gel $60(0.06-0.2 \mathrm{~mm})$, with mixtures of cyclohexane/ethyl acetate $(v / v)$ of increasing polarity, 1:0 (F1, $856 \mathrm{mg}, 3.94 \%), 2: 1$ (F2, 5261 $\mathrm{mg}, 23.91 \%$ ), 1:1 (F3, $3476 \mathrm{mg}, 15.80 \%$ ), 1:2 (F4, $1550 \mathrm{mg}, 6.84 \%$ ), 0:1 (F5, $881 \mathrm{mg}, 4.00 \%$ ), $\mathrm{MeOH}$ (F6, $3942 \mathrm{mg}, 17.92 \%$ ) and acetone (F7, $887 \mathrm{mg}, 4.03 \%)(500 \mathrm{~mL}$ of each eluent). The dichloromethane extract and the correspondent fractions were subjected to a series of in vitro studies, in order to evaluate their antioxidant and neuroprotective potential.

\subsection{Isolation and Characterization of Bioactive Compounds}

Compounds from the most bioactive fraction (F4, $1550 \mathrm{mg}$ ) were isolated by semi-preparative HPLC (Jasco, LC—4000 series, Easton, EUA) by using a reverse-phase column (Synergi Fusion-RP $80 \AA^{\mathrm{a}}$, Phenomenex, $250 \mathrm{~mm} \times 10 \mathrm{~mm}, 4 \mu \mathrm{m}$ semi-preparative column). Compounds were eluted with a gradient of $\mathrm{H}_{2} \mathrm{O} / \mathrm{CH}_{3} \mathrm{CN}$ : isocratic step from 0 to $5 \mathrm{~min}$ (50:50), then, a first gradient step from 5 to $15 \mathrm{~min}$ (50:50 to 100 ) (flow rate $2.0 \mathrm{~mL} \cdot \mathrm{min}^{-1}$, injection volume $200 \mu \mathrm{L}$ ). The first fractionation afforded 16 peaks (F4p1-F4p16), from which fraction F4p10, ( $\mathrm{t}_{\mathrm{R}} 27.5 \mathrm{~min}, 115.5 \mathrm{mg}$ ) was subjected to a more refined purification by PTLC over silica gel plates using $n$-hexane-ethyl acetate $(7: 3)$ as developing system, affording compounds $1(38.8 \mathrm{mg} ; \mathrm{Rf}=0.44)$ and $\mathbf{2}(2.1 \mathrm{mg} ; \mathrm{Rf}=0.71)$. The structures of the two purified compounds were elucidated by nuclear magnetic resonance $\left({ }^{1} \mathrm{H},{ }^{13} \mathrm{C}, \mathrm{APT}, \mathrm{COSY}, \mathrm{HMBC}\right.$ and HSQC). NMR spectra were acquired on a Bruker Avance 400 spectrometer with a frequency of $400 \mathrm{MHz}$ for ${ }^{1} \mathrm{H}$, and $100 \mathrm{MHz}$ for ${ }^{13} \mathrm{C}$. Samples were dissolved in $500 \mu \mathrm{L}$ of $\mathrm{CDCl}_{3}$ (Sigma-Aldrich, St. Louis, MO, USA). Chemical shifts were expressed in ppm and reported to the residual solvent signals. Coupling constants $(J)$ are expressed in Hertz $(\mathrm{Hz})$.

Eleganolone (1): ${ }^{1} \mathrm{H}$ NMR $\left(400 \mathrm{MHz}, \mathrm{CDCl}_{3}\right) \delta 6.06(1 \mathrm{H}, s, \mathrm{H}-14), 5.35(1 \mathrm{H}, t, J=6.8 \mathrm{~Hz}, \mathrm{H}-2), 5.19(1 \mathrm{H}$, $t, J=6.8 \mathrm{~Hz}, \mathrm{H}-10), 5.06(1 \mathrm{H}, t, J=6.7 \mathrm{~Hz}, \mathrm{H}-6), 4.09\left(2 \mathrm{H}, d, J=6.8 \mathrm{~Hz}, \mathrm{H}_{2}-1\right), 2.97\left(2 \mathrm{H}, s, \mathrm{H}_{2}-12\right), 2.11$ $\left(3 \mathrm{H}, s, \mathrm{H}_{3}-17\right), 2.08\left(2 \mathrm{H}, m, \mathrm{H}_{2}-9\right), 2.06\left(2 \mathrm{H}, m, \mathrm{H}_{2}-5\right), 1.99\left(2 \mathrm{H}, m, \mathrm{H}_{2}-4\right), 1.98\left(2 \mathrm{H}, m, \mathrm{H}_{2}-8\right), 1.82(3 \mathrm{H}, s$, $\left.\mathrm{H}_{3}-16\right), 1.61\left(3 \mathrm{H}, \mathrm{s}, \mathrm{H}_{3}-20\right), 1.56\left(3 \mathrm{H}, \mathrm{s}, \mathrm{H}_{3}-18\right), 1.55\left(3 \mathrm{H}, \mathrm{s}, \mathrm{H}_{3}-19\right) ;{ }^{13} \mathrm{C} \mathrm{NMR}\left(100 \mathrm{MHz}, \mathrm{CDCl}_{3}\right) \delta 199.55$ (C-13), 155.68 (C-15), 139.58 (C-3),135.02 (C-7), 129.52 (C-11),129.10 (C-10), 123.92 (C-6), 123.34 (C-2), 
122.80 (C-14), 59.33 (C-1), 55.35 (C-12), 39.46 (C-4), 39.29 (C-8), 27.71 (C-16), 26.70 (C-9), 26.21 (C-5), 20.66 (C-17), 16.36 (C-18), 16.24 (C-20),15.92 (C-19).

Eleganonal (2): ${ }^{1} \mathrm{H}$ NMR $\left(400 \mathrm{MHz}, \mathrm{CDCl}_{3}\right) \delta 9.92(1 \mathrm{H}, d, J=8.0 \mathrm{~Hz}, \mathrm{H}-1), 6.10(1 \mathrm{H}, s, \mathrm{H}-14), 5.87(1 \mathrm{H}$, $d, J=8.0 \mathrm{~Hz}, \mathrm{H}-2), 5.22(1 \mathrm{H}, t, J=6.2 \mathrm{~Hz}, \mathrm{H}-10), 5.09(1 \mathrm{H}, t, J=6.2 \mathrm{~Hz}, \mathrm{H}-6), 3.03\left(2 \mathrm{H}, s, \mathrm{H}_{2}-12\right), 2.22$ $\left(2 \mathrm{H}, m, \mathrm{H}_{2}-4\right), 2.21\left(2 \mathrm{H}, m, \mathrm{H}_{2}-5\right), 2.17\left(3 \mathrm{H}, s, \mathrm{H}_{3}-20,2.14\left(3 \mathrm{H}, s, \mathrm{H}_{3}-17\right), 2.12\left(2 \mathrm{H}, m, \mathrm{H}_{2}-9\right), 2.02(2 \mathrm{H}, m\right.$, $\left.\mathrm{H}_{2}-8\right), 1.88\left(3 \mathrm{H}, \mathrm{s}, \mathrm{H}_{3}-16\right)$, and), $1.61\left(6 \mathrm{H}, s, \mathrm{H}_{3}-18\right.$ and $\left.\mathrm{H}_{3}-19\right) ;{ }^{13} \mathrm{C} \mathrm{NMR}\left(100 \mathrm{MHz}, \mathrm{CDCl}_{3}\right) \delta 199.49$ (C-13), 191.32 (C-1), 163.87 (C-3),155.66 (C-15), 136.30 (C-7), 129.75 (C-11),128.90 (C-10), 127.40 (C-2), 122.86 (C-14), 122.64 (C-6), 55.34 (C-12), 40.56 (C-4), 39.28 (C-8), 27.73 (C-16), 26.68 (C-9), 25.62 (C-5), 20.68 (C-17), 17.60 (C-20),16.40 (C-18), 16.05 (C-19).

\subsection{Antioxidant Activity}

Total Phenolic Content (TPC): the quantification of TPC on B. bifurcata samples was achieved using the Folin-Ciocalteu method adapted to a microscale [52], with minor modifications, and as described by Pinteus et al. [10]. Briefly, $2 \mu \mathrm{L}$ of samples were added to $158 \mu \mathrm{L}$ of distilled water in a 96-well microplate, followed by the addition of $10 \mu \mathrm{L}$ of Folin-Ciocalteu reagent. The reaction mixture was pre-incubated for $2 \mathrm{~min}$ at room temperature, and then $30 \mu \mathrm{L}$ of $20 \% \mathrm{Na}_{2} \mathrm{CO}_{3}(\mathrm{w} / \mathrm{v}$ ) was added and mixed. After $1 \mathrm{~h}$ of reaction in the dark, the absorbance was measured at $755 \mathrm{~nm}$ (Synergy H1 Multi-Mode Microplate Reader, BioTek ${ }^{\circledR}$ Instruments, Winooski, VT, USA). Gallic acid was used as standard. TPC was expressed in milligrams of gallic acid equivalents per gram of dry extract $(\mathrm{mg}$ $\mathrm{GAE} / \mathrm{g}$ of extract).

DPPH Radical Scavenging Activity: this assay was performed according to Pinteus et al. [10]. An aliquot of $2 \mu \mathrm{L}$ of B. bifurcata samples of different concentrations was added to $198 \mu \mathrm{L}$ of DPPH ethanol solution $(0.1 \mathrm{mM})$ to obtain final concentrations of 10, 30, 100, 300 and $1000 \mu \mathrm{g} / \mathrm{mL}$ and the mixtures were then incubated in the dark for $30 \mathrm{~min}$ at room temperature. Results are expressed as mean values \pm SEM (standard error of the mean). $\mathrm{IC}_{50}$ values $(\mu \mathrm{g} / \mathrm{mL})$ were also determined for the extracts with highest activity (DPPH reduction $>50 \%$ ).

Oxygen Radical Absorbance Capacity (ORAC-fluorescein): this assay followed the methodology described by Dávalos et al. [53]. The reaction was carried out in $75 \mathrm{mM}$ phosphate buffer (pH 7.4), and the final reaction mixture was $200 \mu \mathrm{L}$. B. bifurcata samples $(20 \mu \mathrm{L})$, and fluorescein $(120 \mu \mathrm{L} ; 70 \mathrm{nM}$, final concentration) were placed in the wells of the 96-well microplate. The mixture was pre-incubated for $15 \mathrm{~min}$ at $37^{\circ} \mathrm{C}$. Then, AAPH solution $(60 \mu \mathrm{L} ; 12 \mathrm{mM}$, final concentration) was added rapidly, using a multichannel micropipette. The microplate was immediately placed in the reader and the fluorescence $\left(\lambda_{\text {excitation }}: 458 \mathrm{~nm} ; \lambda_{\text {emission }}: 520 \mathrm{~nm}\right.$ ), recorded every minute for $240 \mathrm{~min}$, and automatically shaken prior to each reading. A blank using phosphate buffer instead of the fluorescein and eight calibration solutions, using Trolox $(0-80 \mu \mathrm{M})$ as antioxidant standard, were also carried out in each assay. ORAC values were expressed as Trolox equivalents by using the standard curve calculated for each assay. Final results were expressed in $\mu \mathrm{mol}$ of Trolox equivalents/g of dry extract (or compound) ( $\mu \mathrm{mol} \mathrm{TE} / \mathrm{g}$ of extract (or compound)).

Ferric Reducing Antioxidant Power (FRAP): this method was performed according to Benzie and Strain [54] and Li et al. [29], adapted to a microscale with minor modifications. $\mathrm{FeSO}_{4}$ was used as standard. FRAP reagent was prepared with $0.3 \mathrm{M}$ acetate buffer $(\mathrm{pH}=3.6), 10 \mathrm{mM}$ of TPTZ in $40 \mathrm{mM}$ $\mathrm{HCl}$ and $20 \mathrm{mM}$ ferric solution using $\mathrm{FeCl}_{3}$ in a 96-well microplate. By freshly mixing acetate buffer, TPTZ, and ferric solutions at a ratio of 10:1:1, the final working FRAP reagent was incubated at $37^{\circ} \mathrm{C}$. Briefly, $2 \mu \mathrm{L}$ of $B$. bifurcata samples were added to $198 \mu \mathrm{L}$ of FRAP reagent and allowed to stand at $37^{\circ} \mathrm{C}$ in the dark by $30 \mathrm{~min}$, at which time the increase in absorbance at $593 \mathrm{~nm}$ was measured in the microplate reader. The difference between the absorbance of test compounds and the blank reading was calculated and expressed as $\mu \mathrm{M}$ of $\mathrm{FeSO}_{4} / \mathrm{g}$ of extract (or compound). 


\subsection{Mammalian Cell Strain and Culture Method}

The experiments were performed in an in vitro model of human neuroblastoma SH-SY5Y cells, acquired in the DSMZ (Deutsche Sammlung von Mikroorganismen und Zellkulturen GmbH, strain number ACC 209). Culture conditions were performed according to DSMZ Bank. Briefly, SH-SY5Y cells were cultured in Dulbecco's Modified Eagle's Medium (DMEM) (Sigma-Aldrich, Munich, Germany) supplemented with 10\% ( $v / v)$ of fetal bovine serum (FBS) (Biowest, Riverside, MO, USA) and 1\% of antibiotic/antimycotic commercial solution (Sigma, Rehovot, Israel). For subculture, SH-SY5Y cells were dissociated with trypsin-EDTA (Biowest, Riverside, MO, USA), split into a 1:3 ratio, and subcultured into Petri dishes with $25 \mathrm{~cm}^{2}$ growth area. Culture medium was replaced every 2 days until the cells reached confluence 4-5 days after the initial seeding. Cells were maintained under controlled conditions in a $95 \%$ humidified atmosphere, $5 \% \mathrm{CO}_{2}$, and constant temperature of $37^{\circ} \mathrm{C}$.

\subsection{Neuroprotective Activity}

The neuroprotective effects of B. bifurcata fractions on SH-SY5Y cells treated with 6-OHDA was evaluated as previously described by Silva et al. [9]. Cells were incubated with different fractions of B. bifurcata [F1-F7] in the presence of 6-OHDA at a concentration of $1 \mu \mathrm{g} / \mathrm{mL}$ for $24 \mathrm{~h}$. The solutions were previously prepared in culture medium without FBS and sterile-filtered $(0.2 \mu \mathrm{m}$, Whatman, Maidstone, UK). The effects were assessed by a colorimetric assay based on the conversion of tetrazolium salts (MTT) to blue formazan products by active mitochondria [55].

\subsection{Mechanisms Associated with Neuroprotective Potential}

Quantification of Hydrogen Peroxide $\left(\mathrm{H}_{2} \mathrm{O}_{2}\right)$ : This assay was performed using the Amplex Red Hydrogen Peroxide/Peroxidase Assay kit (Life Technologies, Camarillo, CA, USA), as previously described by Silva et al. [9]. The $\mathrm{H}_{2} \mathrm{O}_{2}$ production was quantified in SH-SY5Y cells after $12 \mathrm{~h}$ of treatment with 6-OHDA $(100 \mu \mathrm{M})$ in the absence or presence of fractions $(1 \mu \mathrm{g} / \mathrm{mL})$ from B. bifurcata. The variation of $\mathrm{H}_{2} \mathrm{O}_{2}$ production was accompanied in real-time for $60 \mathrm{~min}$ at room temperature. Results were expressed in percentage of control.

Mitochondrial Membrane Potential (MMP): MMP was determined using the fluorescent probe, JC-1 (Molecular Probes, Eugene, OR, USA), according to the method described by Silva et al. [9]. The SH-SY5Y cells were treated with 6-OHDA $(100 \mu \mathrm{M})$ for $6 \mathrm{~h}$, in the absence or presence of fractions $(1 \mu \mathrm{g} / \mathrm{mL})$ from $B$. bifurcata. Results were expressed as the ratio of the monomers/aggregates of JC-1 in percentage of control.

Caspase-3 Activity: This activity was assessed using the Caspase-3 Activity Fluorimetric kit (Sigma, Saint Louis, MO, USA), as described previously by Silva et al. [9]. Cells (SH-SY5Y) were cultured in 6-well plates and treated with 6-OHDA $(100 \mu \mathrm{M})$ for $6 \mathrm{~h}$ in the presence or absence of fractions from B. bifurcata $(1 \mu \mathrm{g} / \mathrm{mL})$. Caspase-3 activity was calculated by the slope of the linear phase of the fluorescence resulting from the rhodamine 110 accumulation and expressed in arbitrary fluorescence units per $\mathrm{mg}$ protein per minute ( $\Delta$ fluorescence (a.u.) $/ \mathrm{mg}$ protein $/ \mathrm{min}$ ).

DAPI Staining: The nucleic condensation was determined by 4,6-diamidino-2-phenylindole (DAPI) staining (Applichem, Darmstadt, Germany). SH-SY5Y cells were cultured in 6-well plates and treated with 6-OHDA $(100 \mu \mathrm{M})$ for $24 \mathrm{~h}$ in the presence or absence of B. bifurcata fractions $(1 \mu \mathrm{g} / \mathrm{mL})$. The cells were fixed in paraformaldehyde (4\%) for $30 \mathrm{~min}$. After this time, it was removed, and cells incubated in Triton X-100 (0.1\%) for $30 \mathrm{~min}$. Then, Triton X-100 was removed, followed by the addition of DAPI $(1 \mu \mathrm{g} / \mathrm{mL})$ solution. After $30 \mathrm{~min}$ reaction, DAPI was removed, and $1 \mathrm{~mL}$ PBS (pH 7.4) was added to each well. Then, the cells were observed through a fluorescence microscope (Zeiss, Axio Vert. A1, Oberkochen, Germany). 


\subsection{Statistical Analysis}

One-way analysis of variance (ANOVA) with Dunnett's multiple comparison of group means were employed to determine significant differences relatively to the control treatment. All other post hoc analyses were conducted using Tukey's test. All data were checked for normality and homoscedasticity. Comparisons concerning variables, which did not meet variance or distributional assumptions, were carried out with Kruskal-Wallis non-parametric tests. When applicable, results are presented as mean \pm standard error of the mean (SEM). Differences were considered statistically significant at a level of $0.05(p<0.05)$. All calculations were performed using IBM SPSS Statistics 24 (IBM Corporation, Armonk, NY, USA) and GraphPad v5.1 (GraphPad Software, Inc. La Jolla, CA, USA). The determination of $\mathrm{IC}_{50}$ was calculated by the analysis of non-linear regression using GraphPad Prism software with the equation $Y=100 /\left(1+10\left(X-\log C_{50}\right)\right)$. PCA allowed for the detection of similarities and differences between the different samples, as well as the identification of the main associations between variables that are responsible for the total variability of the data studied. All calculations and graphs produced for the PCA study were performed using the software CANOCO for Windows 4.5 [56].

Author Contributions: J.S. did main experiments (antioxidant, cytotoxicity, neuroprotective assay and hallmarks associated to oxidative stress and apoptosis), J.R. and R.F. were involved in the extraction and fractionation of B. bifurcata. C.A. was involved in the cytotoxic and neuroprotective assays. S.P. was involved in the evaluation of antioxidant activities. A.M. and H.G. were involved in isolation and characterization of compounds. A.A. coordinated the assays related with hallmarks linked to oxidative stress and apoptosis. R.P. conceived and coordinated the study. All authors read and approved the final manuscript and are accountable for the integrity of this manuscript.

Funding: This work was supported by the Portuguese Foundation for Science and Technology (FCT) through Strategic Projects UID/MAR/04292/2013 and UID/Multi/04046/2019 granted to MARE-Marine and Environmental Sciences Centre, and BioISI-BioSystems and Integrative Sciences Institute, respectively, through Red2Discovery Project (PTDC/MAR-BIO/6149/2014), co-financed by COMPETE (POCI-01-0145-FEDER-016791), through Oncologia de Precisão: Terapias e Tecnologias Inovadoras project (POINT4PAC) (SAICTPAC/0019/2015 LISBOA-01-0145-FEDER-016405) and through CrossAtlantic Project (PTDC/BIA-OUT/29250/2017), co-financed by COMPETE (POCI-01-0145-FEDER-029250). This work was also funded by the Integrated Programme of SR\&TD Smart Valorization of Endogenous Marine Biological Resources Under a Changing Climate (reference Centro-01-0145-FEDER-000018), co-funded by Centro 2020 Programme, Portugal 2020, European Union, through the European Regional Development Fund.

Acknowledgments: Authors are very grateful for the financial support of the Projects and Programmes described in funding section. FCT is also acknowledged for the grants attributed to JS (SFRH/BD/103255/2014), CA (SFRH/BD/97764/2013), and SP (SFRH/BD/96203/2013).

Conflicts of Interest: The authors declare no conflict of interest.

\section{References}

1. Ramkumar, M.; Rajasankar, S.; Gobi, V.V.; Dhanalakshmi, C.; Manivasagam, T.; Justin Thenmozhi, A.; Essa, M.M.; Kalandar, A.; Chidambaram, R. Neuroprotective effect of Demethoxycurcumin, a natural derivative of Curcumin on rotenone induced neurotoxicity in SH-SY5Y Neuroblastoma cells. BMC Complement. Altern. Med. 2017, 17, 1-11. [CrossRef] [PubMed]

2. Kao, C.J.; Chen, W.F.; Guo, B.L.; Feng, C.W.; Hung, H.C.; Yang, W.Y.; Sung, C.S.; Tsui, K.H.; Chu, H.; Chen, N.F.; et al. The 1-tosylpentan-3-one protects against 6-hydroxydopamine-induced neurotoxicity. Int. J. Mol. Sci. 2017, 18, 1096. [CrossRef] [PubMed]

3. Ruiz-Torres, V.; Encinar, J.A.; Herranz-López, M.; Pérez-Sánchez, A.; Galiano, V.; Barrajón-Catalán, E.; Micol, V. An updated review on marine anticancer compounds: The use of virtual screening for the discovery of small-molecule cancer drugs. Molecules 2017, 22, 1037. [CrossRef]

4. Debbab, A.; Aly, A.H.; Lin, W.H.; Proksch, P. Bioactive Compounds from Marine Bacteria and Fungi. Microb. Biotechnol. 2010, 3, 544-563. [CrossRef]

5. Pietra, F. Secondary metabolites from marine microorganisms: Bacteria, protozoa, algae and fungi. Achievements and prospects. Nat. Prod. Rep. 1997, 14, 453-464. [CrossRef] [PubMed] 
6. Fischbach, M.A.; Walsh, C.T. Antibiotics for Emerging Pathogen. Science 2009, 325, 1089-1093. [CrossRef] [PubMed]

7. Molinski, T.F.; Dalisay, D.S.; Lievens, S.L.; Saludes, J.P. Drug development from marine natural products. Nat. Rev. Drug Discov. 2009, 8, 69-85. [CrossRef] [PubMed]

8. Yang, N.; Song, F. Bioprospecting of Novel and Bioactive Compounds from Marine Actinomycetes Isolated from South China Sea Sediments. Curr. Microbiol. 2017, 75, 142-149. [CrossRef]

9. Silva, J.; Alves, C.; Pinteus, S.; Mendes, S.; Pedrosa, R. Neuroprotective effects of seaweeds against 6-hydroxidopamine-induced cell death on an in vitro human neuroblastoma model. BMC Complement. Altern. Med. 2018, 18, 58. [CrossRef]

10. Pinteus, S.; Silva, J.; Alves, C.; Horta, A.; Fino, N.; Rodrigues, A.I.; Mendes, S.; Pedrosa, R. Cytoprotective effect of seaweeds with high antioxidant activity from the Peniche coast (Portugal). Food Chem. 2017, 218, 591-599. [CrossRef]

11. Rodrigues, D.; Alves, C.; Horta, A.; Pinteus, S.; Silva, J.; Culioli, G.; Thomas, O.P.; Pedrosa, R. Antitumor and antimicrobial potential of bromoditerpenes isolated from the Red Alga, Sphaerococcus coronopifolius. Mar. Drugs 2015, 13, 713-726. [CrossRef] [PubMed]

12. El Gamal, A.A. Biological importance of marine algae. Saudi Pharm. J. 2010, 18, 1-25. [CrossRef] [PubMed]

13. Santos, S.A.O.; Trindade, S.S.; Oliveira, C.S.D.; Parreira, P.; Rosa, D.; Duarte, M.F.; Ferreira, I.; Cruz, M.T.; Rego, A.M.; Abreu, M.H.; et al. Lipophilic fraction of cultivated Bifurcaria bifurcata R. Ross: Detailed composition and in vitro prospection of current challenging bioactive properties. Mar. Drugs 2017, 15, 340. [CrossRef] [PubMed]

14. Blunt, J.W.; Copp, B.R.; Keyzers, R.A.; Munro, M.H.G.; Prinsep, M.R. Marine Natural Products. Nat. Prod. Rep. 2017, 34, 235-294. [CrossRef] [PubMed]

15. Pereira, L. Seaweed flora of the European North Atlantic and Mediterranean. In Springer Handbook of Marine Biotechnology; Springer: Berlin, Germany, 2015; pp. 65-178, ISBN 9783642539718.

16. Smyrniotopoulos, V.; Merten, C.; Kaiser, M.; Tasdemir, D. Bifurcatriol, a new antiprotozoal acyclic diterpene from the brown alga Bifurcaria bifurcata. Mar. Drugs 2017, 15, 245. [CrossRef] [PubMed]

17. Gallé, J.B.; Attioua, B.; Kaiser, M.; Rusig, A.M.; Lobstein, A.; Vonthron-Sénécheau, C. Eleganolone, a diterpene from the French marine alga Bifurcaria bifurcata inhibits growth of the human pathogens Trypanosoma brucei and Plasmodium falciparum. Mar. Drugs 2013, 11, 599-610. [CrossRef] [PubMed]

18. Göthel, Q.; Lichte, E.; Köck, M. Further eleganolone-derived diterpenes from the brown alga Bifurcaria bifurcata. Tetrahedron Lett. 2012, 53, 1873-1877. [CrossRef]

19. Alves, C.; Pinteus, S.; Simões, T.; Horta, A.; Silva, J.; Tecelão, C.; Pedrosa, R. Bifurcaria bifurcata: A key macro-alga as a source of bioactive compounds and functional ingredients. Int. J. Food Sci. Technol. 2016, 51, 1638-1646. [CrossRef]

20. Pinteus, S.; Silva, J.; Alves, C.; Horta, A.; Thomas, O.P.; Pedrosa, R. Antioxidant and cytoprotective activities of Fucus spiralis seaweed on a human cell in vitro model. Int. J. Mol. Sci. 2017, 18, 292. [CrossRef] [PubMed]

21. Neto, J.; Uchôa, A.; Moura, P.; Filho, C.; Tenório, J.; Silva, A.; Ximenes, R.; Silva, M.; Correia, M. Phytochemical screening, total phenolic content and antioxidant activity of some plants from Brazilian flora. J. Med Plants Res. 2016, 10, 409-416.

22. Farasat, M.; Khavari-Nejad, R.A.; Nabavi, S.M.B.; Namjooyan, F. Antioxidant activity, total phenolics and flavonoid contents of some edible green seaweeds from northern coasts of the Persian gulf. Iran. J. Pharm. Res. 2014. [CrossRef]

23. Manochai, B.; Ingkasupart, P.; Lee, S.H.; Hong, J.H. Evaluation of antioxidant activities, total phenolic content (TPC), and total catechin content (TCC) of 10 sugar apple (Annona squamosa L.) cultivar peels grown in Thailand. Food Sci. Technol. 2018, 1-7. [CrossRef]

24. Costa, L.S.; Fidelis, G.P.; Telles, C.B.S.; Dantas-Santos, N.; Camara, R.B.G.; Cordeiro, S.L.; Costa, M.S.S.P.; Almeida-Lima, J.; Melo-Silveira, R.F.; Oliveira, R.M.; et al. Antioxidant and antiproliferative activities of heterofucans from the seaweed Sargassum filipendula. Mar. Drugs 2011, 9, 952-966. [CrossRef] [PubMed]

25. Kasote, D.M.; Katyare, S.S.; Hegde, M.V.; Bae, H. Significance of Antioxidant Potential of Plants and its Relevance to Therapeutic Applications. Int. J. Biol. Sci. 2015, 11, 982-991. [CrossRef] [PubMed]

26. Liang, T.; Yue, W.; Li, Q. Comparison of the Phenolic Content and Antioxidant Activities of Apocynum venetum L. (Luo-Bu-Ma) and Two of Its Alternative Species. Int. J. Mol. Sci. 2010, 11, 4452-4464. [CrossRef] [PubMed] 
27. Li, J.; O, W.; Li, W.; Jiang, Z.-G.; Ghanbari, H. Oxidative Stress and Neurodegenerative Disorders. Int. J. Mol. Sci. 2013, 14, 24438-24475. [CrossRef] [PubMed]

28. Leyton, A.; Lienqueo, M.E. Purification of phlorotannins from Macrocystis pyrifera using macroporous resins. Food Chem. 2017, 237, 312-319. [CrossRef] [PubMed]

29. Li, Y.; Fu, X.; Duan, D.; Liu, X.; Xu, J.; Gao, X. Extraction and Identification of Phlorotannins from the Brown Alga, Sargassum fusiforme (Harvey) Setchell. Mar. Drugs 2017, 15, 49. [CrossRef]

30. Choi, D.-Y.; Choi, H. Natural products from marine organisms with neuroprotective activity in the experimental models of Alzheimer's disease, Parkinson's disease and ischemic brain stroke: Their molecular targets and action mechanisms. Arch. Pharmacal Res. 2015, 38, 139-170. [CrossRef] [PubMed]

31. Article, R.; Kovacic, P.; Weston, W. Chronicles of Pharmaceutical Science Treatment of Parkinson's Disease with Phenolic Antioxidant Drugs: Oxidative Stress, Reactive Oxygen Species and Selectivity. Pharm. Sci. 2017, 1, 193-198.

32. Brizi, C.; Santulli, C.; Micucci, M.; Budriesi, R.; Chiarini, A.; Aldinucci, C.; Frosini, M. Neuroprotective Effects of Castanea sativa Mill. Bark Extract in Human Neuroblastoma Cells Subjected to Oxidative Stress. J. Cell. Biochem. 2016, 117, 510-520. [CrossRef] [PubMed]

33. Alvariño, R.; Alonso, E.; Tribalat, M.; Gegunde, S.; Thomas, O.P.; Botana, L.M. Evaluation of the Protective Effects of Sarains on $\mathrm{H}_{2} \mathrm{O}_{2}$-Induced Mitochondrial Dysfunction and Oxidative Stress in SH-SY5Y Neuroblastoma Cells. Neurotox. Res. 2017, 368-380. [CrossRef] [PubMed]

34. Souza, R.B.; Frota, A.F.; Sousa, R.S.; Cezario, N.A.; Santos, T.B.; Souza, L.M.F.; Coura, C.O.; Monteiro, V.S.; Cristino Filho, G.; Vasconcelos, S.M.M.; et al. Neuroprotective Effects of Sulphated Agaran from Marine Alga Gracilaria cornea in Rat 6-Hydroxydopamine Parkinson's Disease Model: Behavioural, Neurochemical and Transcriptional Alterations. Basic Clin. Pharmacol. Toxicol. 2017. [CrossRef] [PubMed]

35. Ba, Q.; Cui, C.; Wen, L.; Feng, S.; Zhou, J.; Yang, K. Schisandrin B shows neuroprotective effect in 6-OHDA-induced Parkinson's disease via inhibiting the negative modulation of miR-34a on Nrf2 pathway. Biomed. Pharmacother. 2015, 75, 165-172. [CrossRef] [PubMed]

36. Lou, H.; Jing, X.; Wei, X.; Shi, H.; Ren, D.; Zhang, X. Naringenin protects against 6-OHDA-induced neurotoxicity via activation of the Nrf2/ARE signaling pathway. Neuropharmacology 2014, 79, 380-388. [CrossRef] [PubMed]

37. Perfeito, R.; Perfeito, R.; Rego, A.C. Papel da alfa-sinucleína e da disfunção mitocondrial associada à doença de Parkinson. Rev. Neurocienc. 2012, 20, 273-284.

38. Rodriguez-Pallares, J.; Parga, J.A.; Muñoz, A.; Rey, P.; Guerra, M.J.; Labandeira-Garcia, J.L. Mechanism of 6-hydroxydopamine neurotoxicity: The role of NADPH oxidase and microglial activation in 6-hydroxydopamine-induced degeneration of dopaminergic neurons. J. Neurochem. 2007, 103, 145-156. [CrossRef] [PubMed]

39. Cui, C.; Cui, N.; Wang, P.; Song, S.; Liang, H.; Ji, A. Neuroprotective effect od sulphated polysaccharide isolated from sea cucumber Stichopus japonicus on 6-OHDA-induced death in SH-SY5Y through inhibition of MAPK and NF-kB and activation of PI3K/Akt signaling pathways. Biochem. Biophys. Res. Commun. 2016, 470, 375-383. [CrossRef]

40. Kich, D.M.; Bitencourt, S.; Alves, C.; Silva, J.; Pinteus, S.; Pedrosa, R.; Laufer, S.; de Souza, C.F.V.; Goettert, M.I. Neuromodulatory effects of Calyptranthes grandifolia extracts against 6-hydroxydopamine-induced neurotoxicity in SH-SY5Y cells. Biomed. Pharmacother. 2016, 84, 382-386. [CrossRef]

41. Kaasik, A.; Vassiljev, V.; Poldoja, E.; Kalda, A. Do nuclear condensation or fragmentation and DNA fragmentation reflect the mode of neuronal death? NeuroReport 1999, 10, 1937-1942. [CrossRef]

42. Venderova, K.; Park, D.S. Programmed cell death in Parkinson's disease. Cold Spring Harb. Perspect. Med. 2012. [CrossRef] [PubMed]

43. Chen, W.F.; Chakraborty, C.; Sung, C.S.; Feng, C.W.; Jean, Y.H.; Lin, Y.Y.; Hung, H.C.; Huang, T.Y.; Huang, S.Y.; $\mathrm{Su}, \mathrm{T} . \mathrm{M}$; et al. Neuroprotection by marine-derived compound, 11-dehydrosinulariolide, in an in vitro Parkinson's model: A promising candidate for the treatment of Parkinson's disease. Naunyn-Schmiedeberg's Arch. Pharmacol. 2012, 385, 265-275. [CrossRef] [PubMed]

44. Esmaeili-Mahani, S.; Vazifekhah, S.; Pasban-Aliabadi, H.; Abbasnejad, M.; Sheibani, V. Protective effect of orexin-A on 6-hydroxydopamine-induced neurotoxicity in SH-SY5Y human dopaminergic neuroblastoma cells. Neurochem. Int. 2013, 63, 719-725. [CrossRef] [PubMed] 
45. Daoudi, M.; Ortalo-Magne, A.; Valls, R.; Piovetti, L. (S)-12-Hydroxygeranylgeraniol-derived diterpenes from the brown alga Bifurcaria bifurcata. Phytochemistry 2001, 57, 529-535.

46. Culioli, G.; Ortalo-Magné, A.; Daoudi, M.; Thomas-Guyon, H.; Valls, R.; Piovetti, L. Trihydroxylated linear diterpenes from the brown alga Bifurcaria bifurcata. Phytochemistry 2004, 65, 2063-2069. [CrossRef] [PubMed]

47. Culioli, G.; Daoudi, M.; Mesguiche, V.; Valls, R.; Piovetti, L. Geranylgeraniol-derived diterpenoids from the brown alga Bifurcaria bifurcata. Phytochemistry 1999, 52, 1447-1454. [CrossRef]

48. Ortalo-Magné, A.; Culioli, G.; Valls, R.; Pucci, B.; Piovetti, L. Polar acyclic diterpenoids from Bifurcaria bifurcata (Fucales, Phaeophyta). Phytochemistry 2005, 66, 2316-2323. [CrossRef] [PubMed]

49. Ward, R.; Zucca, F.; Duyn, J.; Crichton, R.; Zecca, L. The role of iron in brain ageing and neurodegenerative disorders. Lancet Neurol. 2014, 13, 1045-1060. [CrossRef]

50. Berg, D.; Youdim, M.B.H. Role of iron in neurodegenerative disorders. Top. Magn. Reson. Imaging TMRI 2006, 17, 5-17. [CrossRef]

51. Kurutas, E. The importance of antioxidants which play the role in cellular response against oxidative/nitrosative stress: Current state. Nutr. J. 2016, 15, 1-22. [CrossRef]

52. Singleton, V.L.; Rossi, J.A., Jr. Colorimetry of Total Phenolics with Phosphomolybdic-Phosphotungstic Acid Reagents. Am. J. Enol. Vitic. 1965, 16, 144-158. [CrossRef]

53. Dávalos, A.; Gómez-Cordovés, C.; Bartolomé, B. Extending Applicability of the Oxygen Radical Absorbance Capacity (ORAC-Fluorescein) Assay. J. Agric. Food Chem. 2004, 52, 48-54. [CrossRef] [PubMed]

54. Benzie, I.F.F.; Strain, J.J. The ferric reducing ability of plasma (FRAP) as a measure of "antioxidant power": The FRAP assay. Anal. Biochem. 1996. [CrossRef] [PubMed]

55. Rotter, B.A.; Oh, Y.N. MTS/PMS colorimetric assay is unsuitable for measuring mitogenic responses in porcine blood lymphocytes. J. Immunol. Methods 1996, 199, 205-209. [CrossRef]

56. Ter Braak, C.J.F.; Šmilauer, P. CANOCO Reference Manual and CanoDraw for Windows User's Guide: Software for Canonical Community Ordination (Version 4.5). In Sect. Permut. Methods Microcomput. Power; Wageningen University \& Research: Ithaca, NY, USA, 2002; Volume 10.

(C) 2019 by the authors. Licensee MDPI, Basel, Switzerland. This article is an open access article distributed under the terms and conditions of the Creative Commons Attribution (CC BY) license (http:/ / creativecommons.org/licenses/by/4.0/). 